\title{
PENGARUH LATIHAN DOUBLE LEG SPEED HOP DAN DOUBLE LEG BOX BOUNDTERHADAP KECEPATAN LARI 100 METER
}

\author{
Sartono \\ STKIP Muhammadiyah Kuningan \\ email: sartonoosh@yahoo.com
}

\begin{tabular}{l} 
Info Artikel \\
\hline Sejarah Artikel: \\
Diterima Desember 2017 \\
Disetujui Desember 2017 \\
Dipublikasikan Januari 2018 \\
\hline Keywords: \\
Kecepatan, Lari, \\
Latihan, Double Leg \\
Speed Hop, Double Leg \\
Box Bound.
\end{tabular}

Box Bound.

\section{Abstrak}

Tujuan penelitian ini adalah untuk mengetahui: (1) Pengaruh latihan double leg speed hop dan double leg box bound terhadap kecepatan lari 100 meter; (2) Latihan yang lebih baik pengaruhnya antara latihan double leg speed hop denganlatihandouble leg box bound terhadap kecepatan lari 100 meter.Metode yang digunakan dalam penelitian ini adalah metode eksperimen dengan rancangan "pretest-posttest design". Populasi dalam penelitian ini adalah mahasiswa putraProgram Studi Pendidikan Jasmani Kesehatan dan Rekreasi Sekolah Tinggi Keguruan dan Ilmu Pendidikan Muhammadiyah Kuningan yang berjumlah 34 mahasiswa. Sampel yang diambil sebanyak 34 mahasiswa. Penelitian ini menggunakan penelitian populasi. Variabel dalam penelitian ini terdiri dari dua variabel, variabel independent yakni latihan double leg speed hopdan double leg box bound, variabel dependent yakni kecepatan lari 100 meter. Seluruh data yang diperlukan dalam penelitian ini diperoleh melalui tes dan pengukuran kecepatan lari 100 meter. Teknik analisis data dengan menggunakan uji perbedaan (t-test) dengan taraf signifikansi $\alpha=0,05$. Berdasarkan hasil penelitian dapat menunjukkan bahwa: (1) ada pengaruh antara latihan double leg speed hop dan latihan double leg box bound terhadap kecepatan lari 100 meter $\left(t_{\text {hitung }}=5,062>t_{\text {tabel }}=2,120\right.$ pada taraf signifikansi 5\%), (2) latihan double leg speed hoplebih baik daripada latihan double leg box bound terhadap kecepatan lari 100 meter. Persentase peningkatan kecepatan lari 100 meterpada kelompok I (kelompok latihan double leg speed hop) $=5,85 \%>$ kelompok II (kelompok latihan double leg box bound $)=2,73 \%$.Kesimpulan dari hasil penelitian ini adalah: (1) ada pengaruh antara latihan double leg speed hop dan latihan double leg box bound terhadap kecepatan lari 100 meter, (2) latihan double leg speedhoplebih baik daripada latihan double leg box bound terhadap kecepatan lari 100 meter.

\footnotetext{
Abstract

The purpose of this study was to find out: (1) Effect of double leg speed hop and double leg box bound training on 100 meters running speed; (2) Better exercise of influence between double leg speed hop training and
} 
double leg box training on 100 meters running speed. The method used in this study is the experimental method with the design of the "pretestposttest design". The population in this study were male students of the Health and Recreation Physical Education Study Program at the Muhammadiyah Kuningan College of Teacher Training and Education, totaling 34 students. The samples taken were 34 students. This study uses population research. The variables in this study consist of two variables, the independent variable is double leg speed hop and double leg box bound training, the dependent variable is the 100 meter running speed. All data needed in this study were obtained through tests and measurements of 100 meters running speed. Data analysis techniques using the difference test (t-test) with a significance level of $\alpha=0.05$. Based on the results of the study, it can be shown that: (1) there is an influence between double leg speed hop training and double leg box bound training on 100 meter running speed $(t$ count $=5.062>$ ttable $=2.120$ at $5 \%$ significance level), (2) double leg training speed hop is better than double leg box bound training for 100 meters running speed. The percentage increase in 100 meter running speed in group I (double leg speed hop training group) $=5.85 \%>$ group II (double leg box bound training group) $=2.73 \%$. Conclusions from the results of this study are: (1) there is influence between double leg speed hop training and double leg box bound training on 100 meter running speed, (2) double leg speedhop training is better than double leg box bound training for 100 meters running speed. 


\section{PENDAHULUAN}

Olahraga merupakan bagian dari kehidupan manusia, dengan berolahraga kesegaran jasmani atau kondisi fisik seseorang dapat ditingkatkan sehingga untuk melaksanakan aktivitas sehari-hari tanpa mengalami kelelahan yang berarti. Melalui kegiatan olahraga dapat membentuk manusia yang sehat jasmani dan memiliki sikap disiplin serta sportif yang pada akhirnya akan membentuk manusia yang berkualitas. Perkembangan olahraga di Indonesia dewasa ini terasa semakin maju. Hal ini tidak terlepas dari peran serta masyarakat yang semakin sadar dan mengerti arti penting dan fungsi olahraga itu sendiri, disamping adanya perhatian serta dukungan pemerintah juga menunjang perkembangan olahraga di Indonesia.

Dalam melaksanakan olahraga manusia mempunyai tujuan yang berbeda, hal ini karena masing-masing manusia melakukan olahraga sesuai dengan tujuan yang diinginkannya. Ada empat dasar yang menjadi tujuan seseorang melakukan kegiatan olahraga. Pertama, adalah mereka yang melakukan olahraga untuk rekreasi, yaitu olahraga untuk mengisi waktu luang. Kegiatan olahraga dilakukan dengan penuh kegembiraan, santai, semua berjalan dengan tidak formal baik tempat, sarana maupun peraturannya. Kegiatan bertujuan untuk penyegaran kembali baik fisik, maupun mental. Kedua, adalah mereka yang melakukan kegiatan olahraga untuk mencapai tujuan pendidikan, seperti olahraga di sekolah-sekolah yang diasuh oleh guru olahraga. Olahraga yang dilakukan adalah formal dengan tujuan mencapai sasaran pendidikan nasional. Kegiatan olahraga ini tercantum dalam kurikulum sekolah dan disajikan dengan mengacu pada tujuan pembelajaran umum dan pembelajaran khusus yang cukup jelas.
Ketiga, adalah mereka yang melakukan kegiatan olahraga untuk tujuan penyembuhan penyakit atau pemulihan sakit.

Olahraga dengan tujuan penyembuhan penyakit atau pemulihan sakit. Olahraga dengan tujuan tersebut dikenal dengan nama olahraga rehabilitasi. Kegiatan olahraga ini dilakukan oleh orang yang menderita sakit atau oleh orang yang telah sembuh dari sakit untuk pemulihan dengan pengawasan dari petugas tertentu (dokter) atau instruktur olahraga. Keempat, adalah sebagai sarana untuk meningkat prestasi dibidang olahraga. Pencapaian prestasi yang tinggi dalam olahraga merupakan salah satu usaha untuk mengharaumkan nama bangsa dan negara. Dengan prestasi-prestasi atlet tersebut akan mendapatkan sebuah penghargaan atau imbalan jasa berupa materi.

Pembinaan olahraga dari cabang olahraga atletik, harus dimulai penerapannya sejak anak-anak usia muda, yang bertujuan untuk mengadakan pembibitan atlet muda berbakat. Untuk mencapai prestasi yang tinggi diperlukan waktu dan proses pembinanan yang panjang, tidak dapat dibuat dan diciptakan dalam waktu yang singkat. Dalam hal ini prestasi yang tinggi bukan hanya dicapai dari bakat atlet itu sendiri, namun dari faktor eksternal yaitu latihan. Metode latihan merupakan suatu cara yang bertujuan untuk meningkatkan kemampuan dan keterampilan seorang atlet, seperti yang dikemukakan Nossek (1982: 63) yang menyatakan bahwa "metode latihan merupakan prosedur dan cara-cara pemilihan jenis-jenis latihan dan penataannya menurut kadar kesulitan, kompleksitas dan beratnya beban". Dengan metode latihan yang baik dan bervariasi, seorang atlet diharapkan dapat mencapai prestasi yang optimal. 
Latihan merupakan faktor yang sangat penting dalam upaya mengasah bakat dan meningkatkan prestasi para atlet. Oleh karena itu diperlukan latihan secara intensif dan terprogram. Latihan intensif merupakan latihan yang dilakukan secara berkesinambungan dengan memperhatikan prinsip-prinsip latihan yang benar sedangkan latihan yang terprogram dengan baik merupakan latihan yang memiliki arah dan tujuan yang jelas, dengan pemberian materi yang sesuai dengan cabang olahraganya, waktu yang tersedia cukup, pembagian waktu yang jelas, serta dengan strategi latihan yang sesuai dengan materi yang diberikan.

Berdasarkan fakta yang ada dilapangan, atlet-atlet atletik Indonesia sampai saat ini sangat sulit bersaing pada event bertaraf internasional. Hal ini disebabkan tidak hanya semata-mata disebabkan oleh kemampuan individual atlet yang kurang, tetapi yang paling bertanggung jawab dengan masalah ini adalah bentuk latihan yang selama ini diberikan. Banyak pelatih baru termasuk pelatih atletik yang memberikan pelatihan yang didasarkan atas pengalaman saat menjadi atlet, hal ini menunjukkan bahwa pelatih belum mampu melakukan inovasiinovasi baru mengenai program latihan yang diberikan, mereka hanya terpaku dengan program latihan yang diberikan selama menjadi atlet sehingga pemanfaatan kemajuan ilmu keolahragaan dan teknologi untuk menerapkan metode latihan yang sesuai belum bisa maksimal.

Pelatihan yang disusun berdasarkan ilmu keolahragaan memperhatikan segala aspek baik dari segi kondisi fisik, perkembangan fisik, psikis, adaptasi fisiologis, dan sebagainya akan menciptakan atlet-atlet yang memiliki potensi tinggi untuk menghasilkan prestasiprestasi yang maksimal. Begitu pula pada saat pelatihan untuk meningkatkan kecepatan lari 100 meter.Lari 100 meter dilakukan dari start sampai finish dengan kecepatan maksimal. Syafrudin (1992: 85) mengemukakan bahwa "lari cepat adalah lari yang dilakukan secepat-cepatnya dalam waktu yang sesingkat-singkatnya pada lari jarak pendek".

$$
\text { Menurut Jarver }
$$
menjelaskan bahwa ada empat fase yang mempengaruhi prestasi lari jarak pendek yaitu (1) fase start yaitu kecepatan reaksi, (2) fase percepatan positif yang menentukan adalah kekuatan tungkai, (3) fase lari dengan kecepatan maksimal adalah panjang langkah, frekuensi langkah, teknik dan koordinasi, (4) dan fase daya tahan kecepatan.

Dalam hal ini mahasiswa putraProgram Studi Pendidikan Jasmani Kesehatan dan Rekreasi Sekolah Tinggi Keguruan dan Ilmu Pendidikan Muhammadiyah Kuningan merupakan salah satu sekolahyang mahasiswanya tersebar dari penjuru daerah di Kabupaten Kuningan itu sendiri, bahkan luar kota, dan kemungkinan terdapat bakat terpendam yang belum tersalurkan khususnya dalam bidang olahraga. Ditinjau dari pelaksanaan kegiatan olahraga telah berjalan dengan baik, namun dari kegiatan yang dilaksanakan khususnya dalam melakukan lari 100 meter para mahasiswabelum bisa menunjukkan kemampuan yang optimal, sehingga prestasi para mahasiswa masih belum maksimal. Masih rendahnya kecepatan lari perlu ditelusuri faktor-faktor penyebabnya, apakah penguasaan tehnik lari yang belum maksimal, kemampuan fisik yang tidak mendukung atau model latihan yang diterapkan kurang tepat.

Kondisi yang demikian seorang pelatih maupun Pembina diharapkan harus mampu mengevaluasi dari berbagai faktor yang ada baik dari pihak pelatih sendiri 
ataukah dari pihak mahasiswa tersebut. Untuk menguasai suatu keterampilan olahraga terutama kemampuan lari 100 meter dibutuhkan cara atau model latihan yang tepat dan sistematis serta harus didukung dengan kemampuan fisik yang memadai dari mahasiswa itu sendiri.Dengan penyusunan program latihan yang tepat, diharapkan dapat mencapai hasil yang maksimal setelah menjalani proses latihan.

Berdasarkan berbagai pertimbangan yang melatar belakangi permasalahan ini, peneliti berkeinginan mengadakan sebuah penelitian pada mahasiswa putra Program Studi Pendidikan Jasmani Kesehatan dan Rekreasi Sekolah Tinggi Keguruan dan Ilmu Pendidikan Muhammadiyah Kuningan untuk meningkatkan kecepatan lari 100 meter dan berkaitan dengan model latihan yang akan peneliti terapkan.Ada berbagai macam bentuk metode latihan untuk meningkatkan kecepatan lari 100 meter.

Dalam hal ini peneliti tertarik pada dua model latihan lari cepat yaitu latihan double leg speed hop dan latihan double leg box bound. Alasan pemilihan kedua latihan lari cepat tersebut karena kedua metode tersebut sama-sama biasa digunakan dalam upaya untuk meningkatkan kecepatan lari dan eksplosif power otot tungkai, walaupun karakteristik kedua latihan lari cepat tersebut sangatlah berbeda. Latihan double leg speed hop merupakan latihan meloncat ke atas kotak dengan ketinggian tertentu kemudian mendarat dari atas kotak dan mulai meloncat lagi ke atas kotak. Menurut M. Furqon H. dan Doewes (2002:34) latihan double leg speed hop merupakan bentuk latihan pliometrik yang bertujuan untuk mengembangkan kecepatan dan power otot tungkai dan pinggul, khususnya kerja otot-otot Gluteals, Hamstring, Quadriceps dan Gastronemius dengan kecepatan tinggi dan penuh tenaga.
Penggunaan kotak ini memberikan beban lebih (overload)pada otot-otot tungkai dan pinggul. Latihan ini memerlukan banyak stabilitas punggung bagian bawah dan daerah togok.

Latihan double leg box bound dilakukan pada permukaan yang rata dan berpegas seperti rumput, matras atau keset. Menurut M. Furqon H. Dan Doewes (2002:30) latihan double leg box bound merupakan bentuk latihan meloncat ke atas ke depan dengan mendarat di atas kotak yang berukuran tinggi 12-22 inci. Latihan ini dilakukan dalam suatu rangkaian loncatan eksplosif yang cepat. Bentuk latihan ini sangat baik untuk mengembangkan kecepatan dan power untuk otot-otot tungkai dan pinggul, khususnya kerja otot-otot gluteals, hamstring, quadriceps, dan gastrocnemius dengan kecepatan yang tinggi dalam meningkatkan kemampuan kecepatan lari 100 meter.

Latihan lari cepat yang digunakan pada penelitian ini adalah latihan double leg speed hop dan latihan double leg box bound. Dengan harapan peneliti dapat mengetahui latihan mana yang paling tepat untuk mengembangkan kecepatan lari. Untuk selanjutnya dalam penelitian ini akan dikembangkan lebih jauh dengan mengambil judul penelitian "Pengaruh Latihan Double Leg Speed Hop dan Latihan Double Leg Box Bound Terhadap Kecepatan Lari 100 Meter pada Mahasiswa PutraProgram Studi Pendidikan Jasmani Kesehatan dan Rekreasi Sekolah Tinggi Keguruan dan Ilmu Pendidikan Muhammadiyah Kuningan".

\section{METODE PENELITIAN}

Metode penelitian yang digunakan adalah eksperimen. Tujuan penelitian eksperimen adalah meneliti ada tidaknya hubungan sebab-akibat serta besarnya 
hubungan tersebut dengan cara memberikan perlakuan terhadap kelompok eksperimen yang hasilnya dibandingkan dengan hasil kelompok yang diberi perlakuan yang berbeda (Sugiyanto, 1994: 21). Adapun rancangan penelitian yaitu "pretest-posttest design".

Pembagian kelompok eksperimen didasarkan pada kecepatan lari 100 meterpada tes awal. Setelah hasil tes awal dirangking, kemudian subjek yang memiliki prestasi setara dipasangpasangkan ke dalam kelompok I dan kelompok II. Dengan demikian kedua kelompok tersebut sebelum diberi perlakuan merupakan kelompok yang sama. Apabila pada akhirnya terdapat perbedaan, maka hal itu disebabkan oleh pengaruh perlakuan yang diberikan. Pembagian kelompok dalam penelitian ini dengan caraordinal pairing sebagai berikut:

\section{HASIL DAN PEMBAHASAN}

Pencapaian tujuan yang diinginkan kecepatan lari 100 meter. Data yang dikumpulkan terdiri dari tes awal secara keseluruhan, kemudian dikelompokkan menjadi dua kelompok, yaitu kelompok 1 dengan perlakuan latihan double leg speed hopdan kelompok 2 dengan perlakuan latihan double leg box bound, serta dari data tes akhir masing-masing kelompok. Data tersebut kemudian dianalisis dengan statistik t-test seperti terlihat pada lampiran. Adapun rangkuman hasil analisis data secara keseluruhan akan disajikan dalam bentuk tabel 1 sebagai berikut:

1. Rangkuman Data pada Kelompok 1

Tabel 3. Deskripsi Data Lari 100 Meter pada Mahasiswa Putra Program Studi Pendidikan Jasmani Kesehatan dan Rekreasi Sekolah Tinggi Keguruan dan Ilmu Pendidikan Muhammadiyah Kuningan dalam penelitian ini dilakukan tes

Tabel 1 Nilai Rata-Rata Lari 100 Meter (Detik)

\begin{tabular}{ccc}
\hline \multirow{2}{*}{ Tes } & Statistik & Nilai \\
\hline \multirow{2}{*}{ AWAL } & Kecepatan terendah & 18,76 \\
\cline { 2 - 3 } & Kecepatan tertinggi & 14,15 \\
\cline { 2 - 3 } & Rata-rata (Mean) & 16,06 \\
\cline { 2 - 3 } & Simpangan Baku (SD) & 1,34782 \\
\cline { 2 - 3 } AKHIR & Kecepatan terendah & 17,62 \\
\cline { 2 - 3 } & Kecepatan tertinggi & 13,90 \\
\cline { 2 - 3 } & Rata-rata (Mean) & 15,12 \\
\cline { 2 - 3 } & Simpangan Baku (SD) & 1,27758 \\
\hline
\end{tabular}


Dari tabel1 dan diagram di atas diketahui bahwa hasil tes awal lari 100 meter pada kelompok 1 memiliki kecepatan terendah 18,76 detik, kecepatan tertinggi 14,15 detik, nilai rata-rata (mean) 15,11 dengan simpangan baku (SD)1,34782. Sedangkan hasil tes akhir kecepatan lari 100 meter padak kelompok 1 memiliki kecepatan terendah 17,62 detik, kecepatan tertinggi 13,90 detik, nilai rata-rata (mean)
15,12 dengan simpangan baku (SD) 1,27758 .

2. Rangkuman Data pada Kelompok 2

Tabel 2. Deskripsi Data Lari 100 Meter pada Mahasiswa Putra Program Studi Pendidikan Jasmani Kesehatan dan Rekreasi Sekolah Tinggi Keguruan dan Ilmu Pendidikan Muhammadiyah Kuningan.

Tabel 2 Nilai Rata-Rata Lari 100 Meter

\begin{tabular}{ccc}
\hline Tes & Statistik & Nilai \\
\hline \multirow{4}{*}{ AWAL } & Kecepatan terendah & 19,35 \\
\cline { 2 - 3 } & Kecepatan tertinggi & 14,31 \\
\cline { 2 - 3 } & Rata-rata (Mean) & 16,12 \\
\cline { 2 - 3 } & Simpangan Baku (SD) & 1,40131 \\
\cline { 2 - 3 } AKHIR & Kecepatan terendah & 18,62 \\
\cline { 2 - 3 } & Kecepatan tertinggi & 14,00 \\
\cline { 2 - 3 } & Rata-rata (Mean) & 15,69 \\
\cline { 2 - 3 } & Simpangan Baku (SD) & 1,21207
\end{tabular}

Dari tabel 2 dan diagram di atas diketahui bahwa hasil tes awal lari 100 meter pada kelompok 2 memiliki kecepatan terendah 19,35 detik, kecepatan tertinggi 14,31 detik, nilai rata-rata (mean) 16,12 dengan simpangan baku (SD)1,40131. Sedangkan hasil tes akhir kecepatan lari 100 meter pada kelompok 2 memiliki kecepatan terendah 18,62 detik, kecepatan tertinggi 14,00 detik, nilai rata-rata (mean) 15,69 dengan simpangan baku (SD)1,21207.

\section{A. Uji Persyaratan Analisis}

Sebelum dilakukan dianalisis, data perlu diuji terlebih dahulu mengenai persyaratan analisisnya. Pengujian persyaratan analisis yang dilakukan yaitu dengan uji reliabilitas, uji normalitas, dan uji homogenitas.

\section{Uji Reliabilitas}

Untuk mengetahui tingkat keajegan hasil tes kecepatan lari100 meter, dilakukan uji reliabilitastest-retest. Hasil uji reliabilitas tes awal dan tes akhir kecepatan lari 100 meter yang dilakukan dalam penelitian ini adalah sebagai berikut: 
Tabel 3. Standar untuk Menginterpretasi Koefisien Reliabilitas

\begin{tabular}{cc}
\hline Koefisien & Reliabilitas \\
\hline $.95-.99$ & Excellent \\
\hline $.90-.94$ & Very good \\
\hline $.80-.89$ & Acceptable \\
$.70-.79$ & Poor \\
\hline $.60-.69$ & Questionable \\
\hline
\end{tabular}

Dari data yang diperoleh sebelum diberikan perlakuan, setelah dianalisis diperoleh nilai $t_{\text {hitung }}$ antara tes awal pada kelompok 1 dan tes awal kelompok $2=$ 0,060 , sedangkan $t_{\text {tabel }}=2,120$. Ternyata nilai $t_{\text {hitung }}$ lebih kecil dari $t_{\text {tabel. }}$ Berarti hipotesis nol diterima. Dengan demikian kelompok 1 dan kelompok 2 sebelum diberi perlakuan dalam keadaan yang seimbang. Antara kelompok 1 dan kelompok 2 berangkat dari titik tolak yang sama, yang berarti apabila setelah diberi perlakuan terdapat perbedaan, hal itu terjadi karena adanya perbedaan perlakuan yang diberikan.

Nilai $\mathrm{t}_{\text {hitung }}$ antara tes awal dan tes akhir pada kelompok $1=11,041$. Sedangkan $t_{\text {tabel }}=2,120$.Ternyata nilai $t_{\text {hitung }}$ lebih besar dari $t_{\text {tabel }}$. Berarti hipotesis nol ditolak, dengan demikian dapat disimpulkan bahwa terdapat perbedaan yang signifikan antara hasil tes awal dan tes akhir pada kelompok 1. Nilai $t_{\text {hitung }}$ antara tes awal dan tes akhir pada kelompok $2=$ 5,508. Sedangkan $t_{\text {tabel }}=2,120$. Berarti hipotesis nol ditolak, dengan demikian dapat disimpulkan bahwa terdapat perbedaan yang signifikan antara hasil tes awal dan tes akhir pada kelompok 2 .

Dari hasil uji perbedaan yang dilakukan terhadap hasil tes akhir pada kelompok 1 dan kelompok 2, diperoleh nilai $t_{\text {hitung }}=5,062$, sedangkan $t_{\text {tabel }}=2,120$. Berarti hipotesis nol ditolak, dengan demikian dapat disimpulkan bahwa setelah diberikan perlakuan, terdapat perbedaan yang signifikan antara hasil test akhir pada kelompok 1 dan kelompok 2. Karena sebelum diberi perlakuan kedua kelompok berangkat dari titik tolak yang sama, maka perbedaan tersebut terjadi karena perbedaan perlakuan yang diberikan.

Pengaruh suatu metode itu bersifat khusus, sehingga perbedaan karakteristik latihan dapat menghasilkan pengaruh yang berbeda. Dengan demikian hipotesis yang menyatakan bahwa ada perbedaan pengaruh latihan double leg speed hop dan latihan double leg box bound terhadap kecepatan lari 100 meter pada mahasiswa putra Program Studi Pendidikan Jasmani Kesehatan dan Rekreasi Sekolah Tinggi Keguruan dan Ilmu Pendidikan Muhammadiyah Kuningan, dapat diterima.

Kelompok 1 yang diberikan perlakuan latihan double leg speed hopmemiliki nilai persentase peningkatan sebesar 5,85\%. Sedangkan pada kelompok 2 yang diberikan latihan double leg box boundmemiliki nilai persentase peningkatan sebesar 2,73\%. Dengan demikian hipotesis yang menyatakan bahwa, pengaruh latihan double leg speed hoplebih baik pengaruhnya dari pada latihan double leg box bound terhadap kecepatan lari 100 meter pada mahasiswa putra Program Studi Pendidikan Jasmani Kesehatan dan Rekreasi Sekolah Tinggi Keguruan dan Ilmu Pendidikan Muhammadiyah Kuningan, dapat diterima. 


\section{SIMPULAN}

Berdasarkan hasil penelitian yang telah dilakukan, dapat diperoleh kesimpulan sebagai berikut:

1. Ada perbedaan pengaruhlatihan double leg speed hop dan latihan double leg box boundterhadap kecepatan lari 100 meter pada mahasiswa putra Program Studi Pendidikan Jasmani Kesehatan dan Rekreasi Sekolah Tinggi Keguruan dan Ilmu Pendidikan Muhammadiyah Kuningan, dengan $t_{\text {hitung }}=5,062>t_{\text {tabel }}$ $=2,120$.

2. Latihan double leg speed hoplebih baik pengaruhnya dari pada latihan double leg box bound terhadap kecepatan lari 100 meter pada mahasiswa putra Program Studi Pendidikan Jasmani Kesehatan dan Rekreasi Sekolah Tinggi Keguruan dan Ilmu Pendidikan Muhammadiyah Kuningan, dengan presentase peningkatan adalah kelompok 1(latihan double leg speed hop) $=5,85 \%>$ kelompok 2 (latihan double leg box bound $)=2,73 \%$.

\section{DAFTAR PUSTAKA}

Abdul Gafur, 1983.Pidato Sambutan Hari Olahraga Nasional ( HAORNAS) I di Solo

Jarver, J. 1974. Principles of Speed an East Europe an Summary. Canberra: The Macmillan Company of Australia PTY LTD.

Mulyono B. 2010. Tes dan Pengukuran. Surakarta: JPOK FKIP UNS.

M. Furqon, H. dan Doewes, M. 2002. Plaiometrik: Untuk Meningkatkan Power.Surakarta: UNS Press.

Nossek. J. 1982. General Theory of Training. Logos: Pan African Press.

Sugiyanto. 1994. Penelitian Pendidikan. Surakarta: UNS Press.

Syafruddin. 1992. Pengantar Ilmu Melatih. FPOK IKIP Padang 